\title{
PERAN MEDIA TANAM DAN PEMBERIAN PUPUK KOMPOS TERHADAP PERTUMBUHAN ANAKAN JABON MERAH Anthocepalus macrophyllus DI PERSEMAIAN
}

\section{THE ROLE OF PLANTING MEDIA AND COMPOST FERTILIZER ON THE GROWTH OF RED JABON Anthocepalus macrophyllus IN NURSERY}

\author{
Budirman Bachtiar \\ Staf Pengajar, Fakultas Kehutanan,Universitas Hasanuddin, Makassar \\ budi_pesan@yahoo.com
}

\begin{abstract}
Abstrak
Penelitian peran media tanam dan pemberian pupuk kompos terhadap pertumbuhan anakan jabon merah Anthocepalus macrophyllus di persemaian. Penelitian ini bertujuan untuk mengetahui interaksi antar perlakuan dosis kompos dan komposisi media tanam yang memberikan pengaruh terbaik terhadap pertumbuhan anakan jabon merah di persemaian. Permberian pupuk kompos dilakukan dengan empat tingkat dosis yaitu, $30 \mathrm{~g} / \mathrm{anakan}, 40 \mathrm{~g} / a n a k a n, 50 \mathrm{~g} / a n a k a n$, dan $60 \mathrm{~g} / a n a k a n$. Sedangkan media tanam berupa campuran antara top soil,pasir,dan sekam padiyang dibuat dalam tiga macam komposisi dengan perbandingan 4:1:1, 3:1:1, dan2:1:1. Hasil penelitian memperlihatkan bahwa perlakuan dosis $50 \mathrm{~g} /$ anakan yang dikombinasikan dengan media tanam pada perbandingan top soil : pasir : sekam padi (4:1:1) memberikan dampak yang terbaik terhadap pertumbuhan anakan jabon merah di persemaian.
\end{abstract}

Kata kunci : media tanam; kompos; jabon merah; persemaian

\begin{abstract}
Research on the role of planting media and compost fertilizers on the growth of red jabon Anthocepalus macrophyllus in nursery. This study aims to determine the interaction between the treatment of compost doses and the composition of the planting media which has the best influence on the growth of seedlings of red jabon in the nursery. Granting compost is carried out with four dose levels, namely, $30 \mathrm{~g} /$ tillers, $40 \mathrm{~g} /$ tillers, $50 \mathrm{~g}$ /tillers, and $60 \mathrm{~g}$ /tillers. While the planting media in the form of a mixture of top soil, sand, and rice husk made in three kinds of compositions with a ratio of $4: 1: 1,3: 1: 1$, and $2: 1: 1$. The results showed that the dosage of $50 \mathrm{~g} /$ tillers combined with the growing media at the top soil, sand, and rice husk ratio $(4: 1: 1)$ had the best impact on the growth of the seedlings of red Jabon in the nursery.
\end{abstract}

Key words: planting media, compost, red jabon, nursery 


\section{Pendahuluan}

Kebijakan yang ditempuh pemerintah Indonesia saat ini dalam upaya mengamnkan danmelestarikan hutan alam tropis yang masih tersisa sebagai sumber plasma nutfah, untuk penurunan emisi karbon, dan dalam rangkapemenuhan kebutuhan kayu yang semakin mengkat adalah dengan mendorongpembangunan hutan tanaman. Bentuk hutan tanaman yang dimaksud adalah Hutan Tanaman Industri (HTI), Hutan Tanaman Rakyat (HTR)dan Hutan Rakyat (HR). Guna merealisasikan terbangunnya hutan tanaman sesegera mungkin dengan produktivitas yang tinggi, maka diperlukan jenis pohon yang memiliki karakteristik diantaranya benih atau bibitnya mudah ditemukan, mudah tumbuh, teknologi budidayanya sederhana, pertumbuhan cepat, bersifat intoleran, dan dapat tumbuh pada lahan-lahan marginal.Salah satu jenis pohon yang memenuhi syarat seperti yang telah diuraikan di atas adalah jabon merah (Anthocephallus macrophyllus).

Jabon merah tergolong tumbuhan pionir yang dapat tumbuh pada berbagi kondisi tanah, seperti tanah bertekstur liat, tanah berbatu, dan tanah alluvial lembab di sepanjang sungai. Keunggulan tanaman jabon dari sisi pemanfaatan yaitu pada umur 5-6 tahun sudah siap dipanen. Bentuk batang silinder dengan tingkat kelurusan yang bagus, dan relatif lebih tahan dari serangan hama dan penyakit (Mulyana dkk, 2010). Jabon adalah jenis kayu yang pertumbuhannya sangat cepat dan dapat tumbuh subur di hutan tropis dengan kisaran ekologi tumbuh pada ketinggian : 0-1000 m dpl, dengan rata-rata curah hujan antara 1500-5000 mm/tahun, perkiraan suhu :21-26 ${ }^{\circ} \mathrm{C}$ dan kondisi reaksi tanah $(\mathrm{pH}): 4,5-7,5$ (Raharja, 2011).

Jabon merah termasuk golongan kelas kuat I sampai II. Sementara dari sisi keawetannya termasuk golongan kelas IV dan kemampuan pori-pori kayu untuk menyerap bahan pengawet tergolong sedang, sebagai bahan baku industri, seperti pulp dan kertas, venir, kayu lapis, industri meubel, dan korek api (BPTH Sulawesi, 2011).

Dengan mempertimbangkan sifat tanaman jabon merah yang cepat tumbuh dan merupakan jenis tanaman asli Indonesia maka pengembangan tanaman ini harus dilakukan secara berkelanjutan untuk bisa memenuhi kebutuhan ekologi maupun kebutuhan ekonomi masyarakat (Mulyana, 2010).dalam rangka mendukung pembangunan hutan tanaman, khususnya jabon maka diperlukan tindakan silvikultur yang dapat merangsang pertumbuhannya sehingga riap tanaman tersebutdapat dipacu dan ditingkatkan sehingga masa panen bisa lebih singkat. salah satu upaya yang dapat dilakukan yaitu dengan menciptakan media tanam yang cocok dan pemberian pupuk kompos yang tepat. Kompos tidak hanya menambah unsur hara, tetapi juga menjaga fungsi tanah sehingga tanaman dapat tumbuh dengan baik (Yuwono, 2005). penelitian ini bertujuan untuk mengetahui peran media tanam dan pemberian pupuk kompos terhadap pertumbuhan anakan jabon merah anthocepalus macrophyllusdi persemaian.

\section{Metodologi Penelitian}

\section{Bahan Penelitian}

Alat yang digunakan dalam penelitian ini adalah kamera, kalliper, mistar ukur, dan alat tulis menuli.Sedangkan bahan yang digunakan dalam penelitian ini adalah anakan jabon, top soil, pasir, dan sekam padi, pupuk kompos, kertas label, dan tally sheet.Penelitian ini dilaksanakan di Hutan Pendidikan UNHAS yang berlokasi di Kabupaten Maros. 


\section{Metode Penelitian}

Desain yang digunakan dalam peneliian ini adalah Rancangan Acak Lengkap Pola Faktorial dengan ulangan sebanyak empat kali. Model matematis percobaan ini adalah :

$$
\begin{array}{r}
Y i j k=\mu+\alpha i+\beta j+\alpha \beta i j+€ i j k \\
i=1, \ldots, 3, j=1, \ldots, 3, k=1, \ldots, 5
\end{array}
$$

Dimana :

Yijk = Nilai pengamatan dari perlakuan ke-ij

$\mu \quad=$ Nilai tengah populasi

ai $\quad=$ pengaruh perlakuan ke-i

$\beta \mathrm{j} \quad=$ pengaruh perlakuan ke-j

$(\alpha \beta) i j=$ pengaruh interaksi antara pupuk ke-i dengan media tanam ke-j

$€ \mathrm{ijk}=$ pengaruh galat percobaan pada bibit jabon ke-k yang memperolehperlakuan ke-ij

Pada penelitian inidicobakan duafaktor yaitu komposisi media tanam dan dosis pupuk kompos,dengan rincian perlakuan sebagai berikut :

1. Faktor pertama adalah media tanam dengan komposisi perbandinganantara top soil : pasir : sekam yang diberi simbol $M$ yang terdiri atas tiga macam komposisi,yaitu:

- $M 1=4: 1: 1$,

- $M 2=3: 1: 1$,

- $M 3=2: 1: 1$.

2. Faktor kedua adalah pupuk komposyang diberi simbol $\mathrm{P}$ yang terdiri atas empat tingkat dosis,yaitu : $\mathrm{P} 1=30 \mathrm{~g} / \mathrm{polybag}, \mathrm{P} 2=40 \mathrm{~g} / \mathrm{polybag}, \mathrm{P} 3=50 \mathrm{~g} / \mathrm{polybag}$, $\mathrm{P} 4=60 \mathrm{~g} /$ polybag

\section{Variabel yang Diamati}

Variabel pertumbuhan yang diamati dan diukur pada penelitian ini adalah : pertambahan tinggi bibit, pertambahan diameter batang, dan pertambahan jumlah daun.

\section{Analisis Data}

Data hasil penelitian dianalisis dengan mengguakan analisisragam, dan untuk mengetahui pengaruh perlakuan terhadap pertumbuhananakan jabon merah, maka dilakukan uji lanjut menggunakan uji Beda Nyata Jujur (BNJ) atau Tukey Test (Gaspersz, 1991) dengan rumus sebagai berikut :

$$
W=q \alpha(p, f e) \cdot S y
$$

Dimana :

$\mathrm{W}=$ Nilai uji Tukey $(\mathrm{BNJ}) \quad \mathrm{q \alpha} \quad=$ Nilai Tabel Tukey

$\mathrm{P}=$ Jumlah Perlakuan $\quad \mathrm{Fe}=$ Derajat Bebas Galat

Sy = Galat Baku Nilai Tengah $(\mathrm{KTG} / \mathrm{r})^{1 / 2} \quad \mathrm{KTG}=$ Kuadrat Tengah Galat

$r \quad=$ Jumlah Ulangan 


\section{Hasil dan Pembahasan}

\section{Pertambahan Tinggi Tanaman}

Tinggi tanaman merupakan ukuran tanaman yang diamati baik sebagai indikator pertumbuhan maupun sebagai parameter untuk mengukur pengaruh lingkungan dan perlakuan yang diterapkan. Hasil penelitian memperlihatkan bahwa dosis pupuk, komposisi media tanam, dan interaksinya berpengaruh nyata terhadap pertambahan tinggi bibit jabon merah.Pengaruh perlakuan terhadap tinggi bibit jabon merah selama penelitian, dapat dilihat pada Tabel 1, 2, dan 3 :

Tabel 1.Hasil Analisis Uji Tukey Pertambahan Tinggi Bibit Jabon Merah pada Kombinasi Perlakuan Komposisi Media Tanam dan Dosis Pupuk (P pada M1).

\begin{tabular}{cccc}
\hline $\begin{array}{c}\text { Kombinasi Perlakuan } \\
\text { Kombinasi Perlakuan }\end{array}$ & $\begin{array}{c}\text { Rata-Rata Pertambahan } \\
\text { Tinggi Bibit }(\mathrm{cm})\end{array}$ & $\begin{array}{c}\text { Hasil Uji Tukey } \\
1,434\end{array}$ & $\underline{0,05}$ \\
\hline M1P3 & 18,4100 & & $\mathrm{a}$ \\
M1P2 & 13,8600 & $\mathrm{~b}$ & \\
M1P4 & 10,5650 & $\mathrm{c}$ & \\
M1P1 & 10,4000 & $\mathrm{c}$ & \\
\hline
\end{tabular}

Ket : Huruf yang sama berarti berbeda tidak nyata pada taraf nyata $5 \%$

Hasil Uji Tukey pada taraf 5\% memperlihatkan bahwa perlakuan M1P3 berbeda nyata dengan perlakuan M1P2, M1P4, dan M1P1. Perlakuan M1P2 berbeda tidak nyata dengan perlakuan M1P1, tetapi berbeda nyata terhadap perlakuan M1P4.

Tabel 2.Hasil Analisis Uji Tukey Pertambahan Tinggi Bibit Jabon Merah pada Kombinasi Perlakuan Komposisi Media Tanam dan Dosis Pupuk (P pada M2).

\begin{tabular}{ccc}
\hline Kombinasi Perlakuan & $\begin{array}{c}\text { Rata-Rata Pertambahan } \\
\text { Tinggi Bibit }(\mathrm{cm})\end{array}$ & $\begin{array}{c}\text { Hasil Uji Tukey } \\
\underline{0,05}\end{array}$ \\
\hline M2P3 & 14,7500 & $\mathrm{a}$ \\
M2P2 & 11,8750 & $\mathrm{~b}$ \\
M2P4 & 11,6250 & $\mathrm{~b}$ \\
M2P1 & 11,5500 & $\mathrm{~b}$ \\
\hline
\end{tabular}

Ket : Huruf yang sama berarti berbeda tidak nyata pada taraf nyata $5 \%$

Hasil Uji Tukey pada taraf 5\% memperlihatkan bahwa perlakuanM2P3 berbeda nyata dengan perlakuan M2P2, M2P4, dan M2P1. Perlakuan M2P2 berbeda tidak nyata dengan perlakuan M2P4 dan M2P1.

Tabel 3.Hasil Analisis Uji Tukey Pertambahan Tinggi Tanaman Semai Jabon Merah pada Kombinasi Perlakuan Komposisi Media Tanam dan Dosis Pupuk (P pada M3).

\begin{tabular}{cccc}
\hline Kombinasi Perlakuan & $\begin{array}{c}\text { Rata-Rata Pertambahan } \\
\text { Tinggi Bibit }(\mathrm{cm})\end{array}$ & $\begin{array}{c}\text { Hasil Uji Tukey } \\
1,434\end{array}$ & $\underline{0,05}$ \\
\hline M3P3 & 17,8150 & a & \\
M3P2 & 14,3280 & b & c \\
M3P4 & 10,3250 & c & \\
M3P1 & 10,1260 & & .
\end{tabular}

Ket : Huruf yang sama berarti berbeda tidak nyata pada taraf nyata $5 \%$ 
Hasil Uji Tukey pada taraf $5 \%$ pada perlakuan M3P3 berbeda nyata terhadap M3P2, M3P4, dan M3P1. Perlakuan M3P4 berbeda nyata dengan M3P2, akantetapi berbeda tidak nyata dengan perlakuan M3P1.

\section{Pertambahan Diameter Batang Tanaman}

Hasil analisis ragam memperlihatkan bahwa dosis pupuk, komposisi media tanam, dan interaksinya berpengaruh nyata terhadap pertambahan diameterbatang bibit jabon merah.Respon pertambahan diameter batang bibit jabon merah dapat dilihat pada Tabel 4, 5, dan 6.

Tabel 5.Hasil Analisis Uji Tukey Pertambahan Diameter Batang Bibit Jabon Merah pada Kombinasi Perlakuan Komposisi Media Tanam dan Dosis Pupuk (P pada M1).

\begin{tabular}{cccc}
\hline Kombinasi Perlakuan & $\begin{array}{c}\text { Rata-Rata Pertambahan } \\
\text { Diameter Tanaman }(\mathrm{mm})\end{array}$ & $\begin{array}{c}\text { Hasil Uji Tukey } \\
0,516\end{array}$ & $\underline{0,05}$ \\
\hline M1P3 & 4,0760 & $\mathrm{a}$ \\
M1P2 & 3,7710 & $\mathrm{ab}$ \\
M1P1 & 3,5385 & $\mathrm{~b}$ \\
M1P4 & 3,2735 & $\mathrm{~b}$ & \\
\hline
\end{tabular}

Ket : Huruf yang sama berarti berbeda tidak nyata pada taraf nyata $5 \%$

Hasil Uji Tukey pada taraf 5\% memperlihatkan bahwa perlakuan M1P3 berbeda tidak nyata terhadap perlakuan M1P2, tetapi berbeda nyata terhadap perlakuan M1P1 dan M1P4.

Tabel 6. Hasil Analisis Uji Tukey Pertambahan Diameter Batang Tanaman Semai Jabon pada Kombinasi Perlakuan Komposisi Media Tanam dan Dosis Pupuk (P pada M2).

\begin{tabular}{cccc}
\hline Kombinasi Perlakuan & $\begin{array}{c}\text { Rata-Rata Pertambahan } \\
\text { Diameter Tanaman }(\mathrm{mm})\end{array}$ & $\begin{array}{c}\text { Hasil Uji Tukey } \\
0,516\end{array}$ & $\underline{0,05}$ \\
\hline M2P3 & 3,5726 & $\mathrm{a}$ & \\
M2P1 & 3,3301 & $\mathrm{a}$ & $\mathrm{a}$ \\
M2P2 & 3,3101 & $\mathrm{a}$ & \\
M2P4 & 2,7012 & $\mathrm{a}$ & \\
\hline
\end{tabular}

Ket : Huruf yang sama berarti berbeda tidak nyata pada taraf nyata $5 \%$

Hasil Uji Tukey pada taraf $5 \%$ memperlihatkan bahwa pada perlakuan M2P3 berbeda tidak nyata terhadap perlakuan M2P1 danM2P2, akan tetapi berbeda nyata dengan perlakuanM2P4. Hal ini menunjukkan bahwa pemberian dosis pupuk kompos dengan dosis $60 \mathrm{~g}$ per tanaman memberikan efek kurang baik terhadap pertambahan diameternya batang anakan jabon merah.

Tabel 7.Hasil Analisis Uji Tukey Pertambahan Diameter Batang Tanaman Semai Jabon pada Kombinasi Perlakuan Komposisi Media Tanam dan Dosis Pupuk(P pada M3).

\begin{tabular}{ccc}
\hline Kombinasi Perlakuan & $\begin{array}{c}\text { Rata-Rata Pertambahan } \\
\text { Diameter Tanaman }(\mathrm{mm})\end{array}$ & $\begin{array}{c}\text { Hasil Uji Tukey } \underline{0.05} \\
0.516\end{array}$ \\
\hline M3P3 & 3,0400 & $\mathrm{a}$ \\
M3P2 & 2,8641 & $\mathrm{a}$ \\
M3P4 & 2,6876 & $\mathrm{ab}$ \\
M3P1 & 2,1302 & $\mathrm{~b}$ \\
\hline
\end{tabular}

Ket : Huruf yang sama berarti berbeda tidak nyata pada taraf nyata $5 \%$ 
Hasil Uji Tukey pada taraf 5\% memperlihatkan bahwa pada perlakuan M3P3 berbeda tidak nyata terhadap perlakuan M3P2 dan M3P4, tetapi berbeda nyata terhadap perlakuan M3P1.

\section{Pertambahan Jumlah Daun Tanaman}

Hasil analisis ragam memperlihatkan bahwa dosis pupuk berpengaruh nyata terhadap pertambahan jumlah daun tanaman sedangkan media tanam dan interaksi antara media tanam dengan dosis pupuk berpengaruh tidak nyata.Hal ini menunjukkan bahwa pemberian pupuk kompos memberikan pengaruh positif terhadap pertambahan jumlah daun tanaman jabon merah. Respon pertambahan jumlah daun dari uji beda dapat dilihat pada Tabel 8.

Tabel 8. Hasil Analisis Uji Tukey Pertambahan Jumlah Daun Tanaman Semai Jabon pada Perlakuan Dosis Kompos

\begin{tabular}{ccc}
\hline Dosis Kompos & $\begin{array}{c}\text { Pertambahan Jumlah } \\
\text { Daun Tanaman }\end{array}$ & $\begin{array}{c}\text { Hasil Uji Tukey } 0,05 \\
0,479\end{array}$ \\
\hline P3 & 7,9500 & $\mathrm{a}$ \\
P2 & 7,5333 & $\mathrm{ab}$ \\
P4 & 7,2023 & $\mathrm{~b}$ \\
P1 & 7,2000 & $\mathrm{~b}$ \\
\hline
\end{tabular}

Ket : Huruf yang sama berarti berbeda tidak nyata pada taraf nyata $5 \%$

Berdasarkan hasil uji Tukey pada taraf $5 \%$ perlakuan dosis pupuk kompos menunjukkan bahwa P3 (dosis pupuk 50 gram/anakan) berbeda tidak nyata terhadap perlakuan P2, tetapi berbeda tidak nyata terhadap perlakuan P4 dan P1.

\section{Pembahasan}

Hasil penelitian memperlihatkan bahwa media tanam yang memberikan pengaruh terbaik terhadap pertambahan tinggi, diameter batang, dan pertambahan jumlah daun anakan jabon merah adalah perlakukan media dengan perbandingan antara top soil : pasir : sekam padi $(4: 1: 1)$.Sedangkan perlakuan pupuk kompos yang memberikan respon terbaik pada pertumbuhan tinggi,diameter batang, dan pertambahan jumlah daun anakan jabon merah adalah pemberian kompos dengan dosis $50 \mathrm{~g}$ per anakan. Hal ini menunjukkan bahwa ketersediaan unsur hara di dalam tanah sangat menentukan keberhasilan pertumbuhan tanaman, apabila terjadi defisiensi unsur hara maka dapat menyebabkan pertumbuhan tanaman terganggu. Hasil tersebut, menjelaskaan kepada kita semua bahwa tanaman yang ditanam pada tanah marginal dengan status hara yang rendah maka pertumbuhannya akan terganggu.Dengan kondisi seperti itu pemupukan sangat diperlukan untuk membantu tanaman dalam penyediaan unsur hara yang dibutuhkan dalam proses pertumbuhannya (Hidalita, 2009).

Faktor faktor yang mempengaruhi proses pertumbuhan dan perkembangan bibit adalah kesuburan media, penggunaan pupuk dan cara penanaman. Untuk pembibitan tanaman kehutanan, komposisi media tanam yang biasa digunakan adalah tanah, kompos, dan arang sekam (Sumarna, 2002).Pengaturan dan perbaikan komposisi media tanam dengan menambahkan sekam padi akan memperbaiki drainase dan aerasi tanah sehingga akar dapat berkembang optimal. Selain itu sekam tersebut akan didekomposisi oleh mikroorganisme yang menghasilkan humus dan unsur hara yang sangat dibutuhkan oleh tanaman. 
Menurut Widianto (1996) dalam Wasis (2011) kompos merupakan bahan organik yang telah didekomposisi oleh mikroorganisme yang dapat memperbaiki sifatsifat tanah, dimana tanah menjadi remah, drainase dan aerasi menjadi baik, unsur hara tersedia sehingga tanaman dapat tumbuh subur pada gilirannnya mikrobamikroba tanah yang bermanfaat dapat hidup lebih subur. Kompos dapat memperbaharui kondisi tanah dan menjadikan tanah disekitar perakaran menjadi lembab dan subur sehingga akar dapat dengan mudah menyerap unsur hara yang terdapat didalamnya (Halawane, dkk., 2011).

Pemberian pupuk kompos berpengaruh nyata terhadap pertambahan diameter anakan jabon.Diameter adalah salah satu karakteristik morfologi tanaman yang merupakan indikator kualitas bibit.Diameter menggambarkan ketahanan bibit dan ukuran system akar, bibit yang berdiameter besar tumbuh lebih cepat dibandingkan dengan bibit yang berdiameter kecil di lapangan.Kompos berperan dalam perbaikan sifat fisik tanah, sehingga pertumbuhan akar menjadi lebih baiksedangkan pertumbuhan diameter batang lebih dipengaruhi oleh faktor genetis tanaman. Pertumbuhan diameter berlangsung apabila keperluan hasil fotosintesis yang digunakan untuk respirasi, penggantian daun, pertumbuhan akar dan tinggi tanaman telah terpenuhi (Mosooli, dkk., 2016).

Kebutuhan hara bagi tanaman tidak selamanya tersedia cukup dalam tanah, dengan demikian perlu ada tambahan hara dari luar tanah itu sendiri.Hara tersebut dapat diberikan melalui pemupukan. Pemupukan adalah penambahan unsur hara yang dibutuhkan oleh tanaman guna meningkatkan produksi dan mutu hasil. Pengalaman menunjukkan bahwa pada tanah yang kekurangan unsur hara tanaman akan mengalami pertumbuhan yang lemah, atau lambat dan bahkan akan menimbulkan kematian pada tanaman (Millang dkk, 2011).

Supriyanto et al. (2014) menyatakan bahwa pemberian pupuk yang berlebihan berpengaruh terhadap perakaran bibit jabon merah oleh karena penimbunan garamgaram mineral tidak dapat diserap oleh akar dan menghambat peresapan hara dan sekaligus menimbulkan keracunan bagi tanaman. indeks garam yang tinggi dapat mengganggu penyerapan air dan nutrisi oleh tanaman (Hamzah dan Silaen, 2018).

Penambahan kompos pada media tanah dapat menambah unsur hara yang dibutuhkan oleh tanaman salah satunya adalah unsur $\mathrm{N}$, dimana unsur $\mathrm{N}$ ini berfungsi untuk pertambahan vegetatif tanaman.Hal ini sejalan dengan pendapat Eko (2010) bahwa nitrogen memiliki peran utama bagi tanaman yaitu merangsang pertumbuhan tanaman secara keseluruhan, terutama batang, cabang, dan daun. Nitrogen juga berperan dalam hal pembentukan zat hijau daun, yang berperan penting dalam proses fotosintesis. Dengan adanya unsur hara yang dibutuhkan tanaman maka jumlah daun dan luas permukaan daun akan bertambah sehingga memperluas bidang permukaan yang tersedia untuk fotosintesis.

\section{Kesimpulan}

1. Kombinasi perlakuan dosis pupuk dan komposisi media tanam memberikan pengaruh positif terhadap pertumbuhan anakan jabon merah.

2. Kompisisi media tanam campuran tanah, pasir, dan sekam padi dengan perbandingan 4:1:1 yang ditambahkan dengan pupuk kompospada dosis40gram/anakan merupakan kombinasi antara dosis pupuk dan komposisi media tanam yang optimal untuk memacu pertumbuhan anakan jabon merah. 


\section{Daftar Pustaka}

BPTH Sulawesi. 2011. Anthocephalus macrophyllus (Roxb.). Miq. Informasi Singkat Benih No 126. November 2011.

Eko, P. 2010. Unsur-unsur Makro yang Dibutuhkan Tanaman.(Online) http:www.ekopras.com/2010/07/06/6-unsur-hara-makro-yang-dibutuhkantanaman (25 Februari 2013).

Gaspersz, V. 1991. Metode Perancangan Percobaan. CV. Armico. Bandung.

Halawane, J. E., H. N. Hidayah, dan J. Kinho, 2011. Prospek Pengembangan Jabon Merah (Anthocephalus macrophyllus (Roxb.) Havil), Solusi Kebutuhan Kayu Masa Depan Badan Penelitian dan Pengembangan Kehutanan Balai Penelitian Kehutanan Manado.

Hamzah dan R. H. Silaen, 2018. Pengaruh Dosis Pupuk Npk (15-15-15) Terhadap Pertumbuhan Bibit Jabon Merah (Anthocephalus macrophyllus Roxb.) Havil) di Pembibitan.Jurnal Silva Tropika e-ISSN 2621-4113 Vol. 2 No. 2 Juni 2018.

Hildalita.2009. Penggunaan Sludge Pabrik Kopi Dalam Produksi Semai Jabon (Anthocephalus Cadamba Roxb Miq.).[Skripsi]. Departemen Silvikultur. Bogor: Institut Pertanian Bogor. Hal 17 dan 19.

Millang, S., Budirman, B. dan Anita, M. 2011.Pertumbuhan Awal Pohon Gaharu (Gyrinops Sp.)Asal Nusa Tenggara Barat di Hutan Pendidikan Universitas Hasanuddin.Jurnal Hutan dan Masyarakat Volume.6, No.2, pp117-123.

Mosooli C. C., M. T. Lasut, J.I. Kalangi, Jos Singgano, 2016. Pengaruh Media Tumbuh Kompos Terhadap Pertumbuhan Bibit Jabon Merah (Anthocephalus Macropyllus). Cocos Jurnal Ilmiah Fakultas Pertanian Univeritas Sam Ratulangi Vol 7, No 3 (2016) Hal 1-11

Mulyana, D. 2010. Mengenal Kayu Jabon Merah dan Putih(2-36 H). Panduan Lengkap Bisnis dan Bertanam Kayu Jabon. Agromedia Pustaka. Jakarta.

Mulyana D, C. Asmarahman, dan I. Fahmi . 2010. Bertanam Jabon. AgroMedia.Jakarta Selatan. Hal 12-14 dan 56

Raharja. 2011. Meraup Untung Besar dari Kayu Jabon. AgroMedia.Yogyakarta. Hal 511 dan 25.

Sumarna, Y. 2002. Budidaya Jati, Jakarta: Penebar swadaya.

Wasis, B, dan Sandrasari, A. 2011. Pengaruh Pemberian Pupuk Kompos terhadap Pertumbuhan Semai Mahoni (Swietenia macrophylla King) pada Media Tanah Bekas Tambang Emas (Tailing).Jurnal Silvikultur Tropika. Vol 03. No 01. Hal 109-112.

Yuwono, D., 2005. Kompos.Penebar swadaya. Jakarta. 